\title{
Pragmatic Analysis of Kamala Das Poetry
}

\author{
Shubhi Bhasin ${ }^{1}$ and Pallavi Srivastava ${ }^{2}$ \\ ${ }^{1}$ (Basic Sciences Department, S.R.M.S. College of Engineering and Technology, Bareilly, India) \\ ${ }_{2}^{2}((B a s i c$ Sciences Department, S.R.M.S. Women's College of Engineering and Technology, Bareilly, India)
}

\begin{abstract}
This paper minutely scrutinizes the poems of Kamala Das which mirror the story of women subjugation, as a man wants, to keep alive the myth of his superiority which leads to bias against women in all spheres of life. In the eye of Kamala Das, even the act of sex itself has the male as aggressor and women as recipient. Various poems of Kamala Das points to the implicit gender bias which affects the lives of women in all spheres of life, all over the world i.e. their standing in society, education, careers, security and above all their very existence in the society. Kamala Das yearns all through her life for true love and affection. She has been immensely frank and dauntless in expressing her physical needs and for this she is severely criticized. She dared to stand on her own and express flawlessly her physical need. Dance of the Eunuchs, one of the most remarkable poems of Kamala Das, has successfully reflected the psychological state of poet as it can be examined on the lines of abjection theory developed by Julia Kristeva. Das poems reflect her sensualism leading to spiritualism in the Radha Krishna portrayal.
\end{abstract}

Keywords: abjection, psychological, spiritualism, subjugation

\section{Introduction}

In the recent times, there has been steady hike in the production of imaginative literature in English by the Indian writers. The consistent efforts by the bright Indians in putting their bright ideas and heightened sensibility in English language have drawn world wide attention. During 20th century, there emerged a great feeling among the poets, writers and scholars of different countries writing in English to establish, the identity of their own writings as a distinctive force of their own cultural heritage and literary enterprises. With the receding of the romantic tradition, the second wave of Indian poetry in English emerged just around the beginning of post-Independence era. R. Parthasarathy's Ten Twentieth-century Indian Poets publicized the works of the 'academic' poets, among whom the most audacious - particularly in her protests against patriarchy and embracing of matrilineal culture with a romantic fervor, the exploration of female sexuality and the sexual desires of women,(1) is Kamala Das.

Kamala Das, also known as Madhavikutty in her mother-tongue, Malayalam, is a trail blazer in the Indian English Poetry. Kamala Das has served the Indian English literature immensely. Her most remarkable achievement is writing an Indian English. Often her vocabulary, idioms, choice of words and some syntactical construction are part of what has been termed the Indianization of English. This is an accomplishment. It is important in the development of the national literature that writers free themselves from the linguistics standard of their colonizers and create a literature based on local speech." (2). According to Eunice de Souza women writers owe a special debt to Kamala Das as - "She mapped out the terrain for post-colonial women in social and linguistic terms."(3)

Kamala Das' poems epitomize the dilemma of the modern Indian women who attempt to free her sexually and domestically from the role bondage sanctioned to her by the patriarchal society. "Kamala's poetry embodies agonies of women emerging from that state of subjugation and bondage, and seeking to establish their identity and the self." (4) In fact Kamala Das has come on the Indo-English poetic scene at a time when there has been a heightening of interest in the works of women all over the world. This is because there has been a rethinking and a re-interpretation of the traditional role of women and the consequent emancipation of women in a male-dominated universe. Arlene R.K. Zide opines:"Kamala Das' themes transcend the 'personal' because what she attempts to poetize, is the 'Universal experience' of a woman"(5).

\section{Discussion}

The poetry of Kamala Das is characterized by a daring frankness, a total lack of inhibitions especially with reference to love and sex, this marked her as iconoclast. Her poems when focused upon love treats it within more panoptic ranges of themes, more realized settings and with soft feelings, bringing to it an intensity of emotion and speech. She is a revolutionary writer. Her voice is authentic, honest, frank, human to core, persuasive, and above all female. In her poems she expresses her inner pangs caused by marriage. She feels a sense of loss and suffocation for marriage commodifies her, crushes her soul, her spirit, her liberty and her 
essence as a women. Kamala Das has been regarded as a truly authentic feminine voice of power dealing with "conflict between passivity and rebellion against the male oriented universe". Her poetry to Devendra Kohli is "in the final analysis and acknowledgment and a celebration of the beauty and courage of being women". Kamala Das poems are pre-eminently poem of love- love which includes anguish and pain in a "near- neurotic world". Her world of love is especially a personal world, depicting the agonizing ambivalence of the search for security in love even while desiring "independence consistent with a non-domestic mode of living". The failure to discover this meaningful relationship between the sexes invests bordering on tragedy. She makes public, traditionally private experiences, suggesting that women's personal feelings of longing and loss are the part of the collective experience of womanhood. In the collection, The Descendants, the poem "The Maggots" names the pain of lost love with ancient Hindu myths, while the poem "The Looking-Glass" suggests that the very thing society labels taboos are the things that women are supposed to follow. In the Old Playhouse and Other Poems, poems such as "Substitute", "Gino", and "The Suicide" examine physical love's failure to provide fulfillment, escape from the self, and exorcism of the past, whereas poems such as "The inheritance" addresses the integrity of the artistic self in the face of religious fanaticism.

Dance of the Eunuchs is one of the most remarkable poems of Kamala Das. The poet vividly conjures up the atmosphere of a hot, tortured, corrupt, sterile and barren world through vivid symbols and images. The dance of the eunuchs whose joyless life reflects the poet's fractured personality is a noticeable piece of autobiographical poetry. Kamala Das has vividly visualized the world of "vacant ecstasy" and sterility through numerous functional images and symbols in her poetry. In fact Eunuchs try to eke out a livelihood by dancing. Their dancing is mechanical and painful. The conditions and the climate are forbidding. The spectators are merciless. Even God seems to add their woes. The eunuchs' voices are harsh and their songs are full of melancholy. The themes of the songs are those of lovers dying and children left unborn. Some beat their drums while others beat their flat breasts and wept. The joy on their faces is only a mask as they writhe in pain and their faces are really vacant. The atmosphere of heat and sterility is, first of all, expressed through "fiery gulmohur" and "the jasmines in, their hair" could not provide them with a soothing effect. The image of "Their sour breasts" again suggests their sterility and barrenness because they belong to neither sex. They are destined to remain unfulfilled. In fact their personality reflects the psychological outburst of the poet. It can be examined on the lines of abjection theory developed by Julia Kristeva "The abject is that which is rejected by social reason- the communal consensus that underpins a social order" (6). "The abject exists accordingly somewhere between the concept of an object and the concept of the subject representing taboo elements of the self barely separated off in a liminal space"(7) According to Julia Kristeva- "The abject is situated outside the symbolic order, being forced to face it is an inherently traumatic experience, as with the repulsion presented by confrontation with filth, waste or a corpse- an object which is violently cast out of the cultural world, having once been a subject" Similarly the highly suggestive images of:

................... a meager rain that smelt of dust in

Attics and the urine of lizards and mice...." (8)

highlight the depressed and dejected mental state of Kamala Das. According to Kristeva's theory of abjection, fear is the dominant/operative word. Making a connection between language and phobia, Kristeva claims that "phobia does not disappear but slides beneath language" and "any practice of speech, in as much as it involves writing, is a language of fear" (9). Similarly the heightened sensibilities of the poet through the picturisation of the external factors forge the image of the psychological state of the poet herself.

"It is a poem that successfully delineates the contrast between the superficial joy and the inner depravity. The eunuchs become the objective correlative of suppressed desires". (10) There is much anguish and suffering in the verse of Kamala Das. Poem corresponds her own feeling of persecution and inadequacy. Her feminine self finds the man emotionally deficient and incapable of possessing a passionate regard for concrete reality. Her feminine self is an outcome of the cruelty, tyranny and indifferent attitude of man. She mourns in her works stating her pitiable condition. A number of poems in 'The Descendants' deal with the theme of loveaffairs resulting in uselessness. 'The Looking Glass' functions as a comic-relief in the same intensity as it functions in a way to mock at the cruelty of man towards his counterpart. It gives unwonted pleasure to man to think ill and negative about his wife. He is happy to see his physical strength and takes for granted that he also leads intellectually. In a male dominated world, it depends on woman to satisfy the male ego by admiring his male prowess by showing her own feminine weakness. Her soft, lovely feminine self serves two duties, first to excite his passion and - second to gratify his vanity as a superior male. Her feminine self also learns how to get a man to satisfy her lust as in "The Looking Glass"

"Getting a man to love you is easy

Only be honest about your wants as

Woman. Stand nude before the glass with him

So that he sees himself the stronger one 
And believes it so, and you so much more

Softer, younger, lovelier.

Gift him all" (11)

Her upbringing by careless parents, marriage to an egoistic and vainglorious man, disappointment in love, and illicit love -affairs with other men in order to remove her boredom and anxiety, rendered her vision tragic. Kamala Das is unhappy as one of the few brown children in a white school. She thinks that white parents support their children more than Indian parents. Young Kamala Das wonders, "Why I was born to Indian parents instead of to a white couple, who may have been proud of my verses" (12). She believes that marriage means endless sacrifices, household chores, loss of freedom and frustration.

This is clearly depicted by Das in "The Old Playhouse": "You planned to tame a swallow, to hold her in the long summer of your love so that she would forget not the raw seasons alone, and the homes left behind, but also her nature, the urge to fly, and the endless Pathways of the sky" (13). Her dissatisfaction in marriage and life sharpened her consciousness, and she possibly decided to air out her grievances through the medium of poetry and so imagery and symbols in Kamala Das' poetry are suggestive and functional. They are not mere decorations. Her images are drawn from the familiar and the common place, and they poetically reveal her own life. Das' uncanny honesty extends to her exploration of womanhood and love. In her poem "An Introduction" from Summer in Calcutta, the narrator says, "I am every Woman who seeks love"(14). Anisur Rahman reinforces this view when he comments that "she views the male body as an agent of corruption" and also "regards it as a symbol of corrosion, the destroyer of female chastity" (15), and this image is the result of the constant suffering which she experiences throughout her life. Though Amar Dwivedi criticizes Das for this "self imposed and not natural" universality, this feeling of oneness permeates her poetry (16). In Das' eyes, womanhood involves certain collective experiences. Indian women, however, do not discuss these experiences in deference to social mores. Das consistently refuses to accept the silence of her lot. Her feelings, longing and loss are not confined to a private misery. In fact they are invited into the public sphere and are acknowledged. Das seems to insist that her feelings are normal and have been felt by women across time and place. In "The Maggots" from the collection, The Descendants, "Das corroborates just how old the sufferings of women are. She frames the pain of lost love with ancient Hindu myths" (17). On their last night together, Krishna asks Radha if she is disturbed by his kisses. Radha says, "No, not at all, but thought, what is it to the corpse if the maggots nip?"As- The Maggots (The Descendants)

"At sunset, on the river bank, Krishna

loved her for the last time and left...

That night in her husband's arms, Radha felt

so dead that he asked, what is wrong,

do you mind my kisses, love? And she said,

no, not at all, but thought, what is

it to the corpse if the maggots nip?" (18)

Radha's pain is searing, and her silence is given voice by Das. Furthermore, by making a powerful goddess prey to such thoughts, it serves as a validation for ordinary women to have similar feelings.

Her unfulfilled love, lusts and sexual bouts, agony and anguish, sterility and inner vacuity, sadness, disease, sickness and death wish are expressed through the images of human body, sun and heart, burial and cremation, nature, sex, sleep and the myth of RADHA and KRISHNA. K.R.S. Iyegar remarks: "The images are icy, stony, steely, and dark -"settle time like a paper weight" or "dies with metallic sighs" or "the night, dark cloaked like a procuress" and are meant perhaps to insulate the true self from the surface life." A search for love is the principal preoccupation of Kamala Das's poetry. She confesses with utmost candour that she "began to write poetry with the ignoble aim of wooing a man" commented Nissim Ezekiel. Love becomes the pervasive theme for her and it is through love that she endeavors to discover herself. It is not the physical love that Das longs for. What she craves for is an emotional bonding with her man. But, to her surprise, she receives the carnal pleasures from him:

She even cries as-

"Ah, why does love come to me like pain

Again and again and again?"

(Summer in Calcutta 19)

Kamala Das soon discovers that a love that flourishes and thrives in a body is bound to wither with it and the search for true love, in a world of philanderers, is a futile exercise. So, the search for human love turns to love for the immortal one, that is, "Lord Krishna." In psychological terms, Krishna, as Sudhir Kakar remarks, "encourages the individual to identify with an ideal primal self, released from all social and superego 
constraints. Krishna's promise, like that of Dionysus in ancient Greece, "is one of utter freedom and instinctual exhilaration" Krishna plays a therapeutic role in the poet's life when she cries in "Radha":

Everything in me

Is melting, even the hardness at core

O Krishna, I am melting, melting, melting

Nothing remains but

You. (The Descendants)(20)

Kamala Das longed for ideal love which she found in spiritual experience. Being fed up with the temporary salutary effects of physical and carnal pleasure, she resorts to the pure love of 'Radha-Krishna. She gives a contrasting image of this love thus:

"This becomes from this hour

Our river and the old Kadamba

Tree, ours alone, for our homeless

Souls to return someday

To hang like bats from it's pure

Physicality. ..."

(Summer in Calcutta)(21)

The metamorphosis from carnal to spiritual can be viewed as Das's inner urge to rise above the merely earthly pleasures and to procure a pure bond of love. This Radha-Krishna syndrome is an open assertion of the pure relationship which she seeks desperately throughout her life. She hears the pricks of her soul within her body and believes that declining of her body has nothing to do with the dignity of soul.

\section{Conclusion}

Thus, Das is an important figure whose bold and honest voice has re-energized Indian writing in English. Das has attempted to touch and feel life in a meaningful way and there lies a dualism in her writing in English, in which soul is contrasted to body. Her poems are filled with yearning for death which symbolizes calmness in contrast to the conscious mind and the body of the anxious individual. Her realization of the supremacy of spirit over matter, soul over body, timeless over the temporal is suggestive of a maturity in her creative art. As an Indian writer and poet Das champions the causes of superiority of spirit over matter, as in some poems like "RadhaKishan" and "Vrindavan" she has attempted to find a mythic equivalent for her search for true love. Her offended feminine self went on emotional wanderings attempting to explore an identity and freedom. As a woman she tries to see man woman relationship in its purest and idealized form. So dualism results from the fall from childhood innocence into the adult realm of sexuality, marriage and life amongst strangers. Her sympathetic understanding explication and revelation of the problem of Indian woman in general, obviously make her feminist. In the words of K.R. Srinivasa Iyengar, "aggressively individualistic," is Kamala Das aka MadhaviKutty, the so-called icon of Indian feminism. (22)

\section{References}

[1] The Hindu, The Feminine Sensibility of Kamala Das by M.S. Nagarajan, 23 Aug., 2011

[2] Bruce Alvin King (1987), Modern Indian Poetry in English, (rev.ed.2001), New Delhi: Oxford University Press.

[3] Eunice de Souza, (1997) Nine Indian Women Poets: An Anthology. (Delhi: Oxford University Press.)

[4] K. Manmohan Bhatnagar, (2002) Feminist English Literature (New Delhi: Atlantic Pub. and dis.), p. 7.

[5] R.K. Arlene Zide ,(1981) The Old Play House And Other Poems (Journal of South Asian Ltd.), p. 239

[6] Julia Kristeva, Power of Horrors: An Essay on Abjection (1982) p.65

[7] J Childers /G.Hentzi, The Columbia Dictionary of Modern Literary and Cultural Criticism(1995), p308

[8] Kamala Das, (1965) Summer in Calcutta.( Dance of the Eunuchs)

[9] Julia Kristeva, Power of Horrors: An Essay on Abjection (1982)

[10] Vandana Datta, (1995-1996) Landmarks in Indian English Poetry, The Indian Journal of English Studies, Vol.xxxiv (New Delhi).

[11] Das Kamla, (1967) The Descendants (Calcutta: Writer's workshop,), p. 25.

[12] Sezer Sabriye Ikiz Research paper on Kamala Das's My Story, Ege University Turkey.

[13] Kamala Das, The Old Playhouse and Other Poems

[14] Kamala Das, An Introduction from Summer in Calcutta.

[15] Anisur Rahman, (1981) Expressive Form in the Poetry of Kamala Das (New Delhi: Abhinav Publications,):p38.

[16] A.N Dwivedi, (1979) Indo-Anglian Poetry. Allahabad: Kitab Mahal,

[17] Eunice de Souza, (1997), Nine Indian Women Poets. Delhi: Oxford University Press.

[18] Kamala Das, The Maggots ( The Descendants)

[19] Kamala Das, (1965) Summer in Calcutta

[20] Kamala Das, (1967) The Descendants, (Calcutta: Writers Workshop)

[21] Kamala Das, (1965) Summer in Calcutta.

[22] The Hindu, The Feminine Sensibility of Kamala Das by M.S. Nagarajan, 23 Aug., 2011 